Quality : Jurnal Kesehatan

Volume 15, Nomor 1 Tahun 2021

pISSN : 1978-4325, eISSN : 2655-2434, DOI: 10.36082/qjk.v15i1.199

\title{
PENGARUH PENERAPAN TEKNIK RELAKSASI AUTOGENIK TERHADAP TINGKAT KECEMASAN IBU HAMIL PRIMIGRAVIDA
}

\author{
Vera Iriani Abdullah ${ }^{1}$, Rina Andika Saputri Ikraman ${ }^{2,}$ Harlina $^{3}$ \\ 1,3 Jurusan Kebidanan, Politeknik Kesehatan Kemenkes Sorong, Indonesia \\ ${ }^{2}$ Puskesmas Teluk Manyailibit, Dinas Kesehatan Kabupaten Raja Ampat, Indonesia
}

\begin{tabular}{ll}
\hline Info Artikel & Abstrak \\
\hline Genesis Naskah: & Relaksasi autogenik adalah salah satu tehnik yang bersumber dari diri sendiri \\
& berupa kata-kata atau kalimat pendek yang bisa membuat pikiran tentram. \\
Submitted: 20-02-2021 & Relaksasi autogenik dilakukan dengan membayangkan diri sendiri berada dalam \\
Revised: 11-01-2021 & keadaan damai dan tenang, berfokus pada pengaturan nafas dan detak jantung \\
Accepted: 24-05-2021 & sehingga menurunkan ketegangan fisiologis pada ibu hamil. Ibu primigravida \\
& berpeluang lebih besar mengalami kecemasan, yang secara langsung dapat \\
& memberikan respon secara fisiologis berupa peningkatan denyut jantung, sehingga \\
Kata Kunci: & berdampak pada kesehatan ibu dan janin. Tujuan penelitian untuk mengetahui \\
Relaksasi, Autogenic, kehamilan & pengaruh teknik relaksasi autogenik terhadap tingkat kecemasan ibu hamil \\
& Primigravida. Penelitian ini menggunakan metode Quasi eksperimen, dengan \\
& desain One Group Pretest Posttest. Populasi penelitian adalah ibu hamil di wilayah \\
& kerja 54 Puskesmas Waisai Kabupaten Raja Ampat tahun 2020. Jumlah sampel \\
& sebanyak 33 responden yang memeuhi kriteria inklusi dan eklusi menggunakan \\
& teknik Purposive Sampling. Pengukuran tingkat kecemasan menggunakan skala \\
& HARS (Hamilton Anxiety Rating Scale), sedangkan uji bivariate menggunakan uji \\
& Wilcoxon. Hasil menunjukkan nilai p 0,000 < 0,05, kesimpulan teknik relaksasi \\
& aoutogenik secara signifikan dapat mempengaruhi penurunan tingkat kecemasan \\
& pada ibu hamil Primigravida. \\
\hline
\end{tabular}

\section{THE EFFECT OF APPLICATION OF AUTOGENIC RELAXATION TECHNIQUES ON ANXIETY LEVEL OF PREMIGRAVED MOTHERS}

Keywords

Relaxation,Autogenic,Pregnant

\begin{abstract}
Autogenic relaxation is a technique that comes from itself in the form of words or short sentences that can make the mind peaceful. Autogenic relaxation is carried out by imagining oneself in a state of peace and calm, focusing on regulating breath and heart rate so as to reduce physiological tension in pregnant women. Primigravida mothers have a greater chance of experiencing anxiety, which can directly respond physiologically in the form of an increase in heart rate, thus impacting the health of the mother and fetus. The research objective was to determine the effect of autogenic relaxation techniques on the anxiety level of Primigravida pregnant women. This study used a Quasi-experimental method, with a One Group Pretest Posttest design. The study population was pregnant women in the work area of 54 Puskesmas Waisai, Raja Ampat Regency in 2020. The total sample was 33 respondents who met the inclusion and exclusion criteria using
\end{abstract}

(C) Poltekkes Kemenkes Jakarta I

J1. Wijaya Kusuma No. 47-48 Cilandak Jakarta Selatan, Indonesia email: jurnalquality@poltekkesjakarta1.ac.id
ISSN 2655-2434

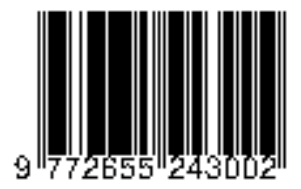


purposive sampling technique. The measurement of anxiety level uses the HARS (Hamilton Anxiety Rating Scale) scale, while the bivariate test uses the Wilcoxon test. The results showed a $p$ value of $0.000<0.05$, the conclusion that aoutogenic relaxation techniques can significantly affect the reduction of anxiety levels in Primigravida pregnant women.

\section{Korespondensi Penulis:}

Vera Iriani Abdullah

Jl. Basuki Rahmat Km. 11, Kota Sorong

email:verabdullah1977@gmail.com 


\section{Pendahuluan}

Kecemasan merupakan gangguan psikiatri yang paling umum terjadi di seluruh dunia. Depresi atau kecemasan selama kehamilan merupakan salah satu komplikasi kehamilan yang paling sering terjadi, bukti menunjukkan efek buruk dapat terjadi pada janin, seperti terhambatnya pertumbuhan intrauterin dan kelahiran prematur, serta terganggunya perkembangan saraf pada bayi (Pinto et al., 2017).

Sedangkan pada Ibu dapat menyebabkan terjadinya preeklampsia, arteri dan hipertensi Kecemasan pada saat kehamilan dapat menyebabkan gangguan mood dalam jangka waktu panjang atau permanen (Salgado et al., 2020). Hal ini disebabkan karena pada masa kehamilan terjadi perubahan baik secara fisik maupun psikologis sehingga wanita hamil lebih rentan mengalami gangguan psikologis, seperti kecemasan, stres, dan depresi (Omidvar et al., 2018).

Ibu primigravida lebih beresiko mengalami kecemasan. Hal ini disebabkan karena ketakutan akan timbulnya kecacatan pada janin, masalah dalam persalinan serta takut akan rasa nyeri (Tri susilowati, 2020). Kecemasan, jika tidak diobati, dapat menyebabkan dampak buruk bagi ibu dan juga janin (Mumtaz \& Akram, 2020). Untuk itu perlu dilakukan penangganan secara tepat. Penggunaan dengan motode farmakologi merupakan metode utama namun ini bukanlah bagian dari kewenangan Peneliti sebagai seorang Bidan. Untuk itu Peneliti lebih tertarik untuk menggunakan metode non farmakologi.

Beberapa metode non farmakologi secara signifikan dapat menanggani kecemasan diantaranya desensitisasi sistematis, relaksasi, pemaparan, pemodelan, pelatihan tegas, dan teknik pengendalian diri (Mumtaz \& Akram, 2020). Selain itu terapi yoga, terapi meditasi, terapi thai chi dan relaksasi otot progresif juga dapat membantu menanggani kecemasan Sulastri dan Lismarini, 2018)

Teknik relaksasi autogenic merupakan salah satu teknik relaksasi yang dapat melatih seseorang masuk dalam situasi atau keadaan santai. Hal ini akan mengeluarkan energy positif yang secara langsung dapat mempengaruhi psikologi ibu dan berdampak pada kehamilan dan janin (Umam et al., 2020). Hingga saat ini kecemasan belum diketahui

(C) Poltekkes Kemenkes Jakarta I

Jl. Wijaya Kusuma No. 47-48 Cilandak Jakarta Selatan, Indonesia email: jurnalquality@poltekkesjakarta1.ac.id penyebabnya secara langsung. hal ini sejalan dengan studi yang dilakukan di Mexico Tahun 2019 menunjukkan bahwa factor ekonomi, emosional, dan sosial tidak selamanya dapat menjadi factor pemicu terjadinya depresi atau kecemasan, karena Ibu hamil yang memliki usaha perseorangan dan sebagai pekerjaan kantoran dengan ekonomi baik juga dapat mengalami kecemasan (Salgado et al., 2020).

Pada saat hamil, hormon adrenalin akan meningkat, hal ini menyebabkan terjadinya disregulasi biokimia sehingga tubuh mengalami ketegangan fisik akibatnya ibu hamil akan mudah marah, gelisah, tidak mampu memusatkan pikiran, ragu-ragu bahkan mungkin ingin lari dari kenyataan hidup. Keadaan ini cenderung terjadi pada ibu primigravida (Manalu et al., 2020).

Pelatihan relaksasi secara signifikan memiliki efek untuk mengurangi kecemasan tanpa penggunaan obat, bahkan pada wanita hamil dengan kondisi medis yang serius (Mumtaz \& Akram, 2020). Hal ini sejalan dengan studi yang dilakukan pada 46 ibu hamil, menunjukkan bahwa kombinasi relaksasi autogenik dan Benson pada Ibu hamil dapat meningkatkan kualitas tidur (Umam et al., 2020). Dengan kualitas tidur yang baik maka secara langsung akan mempengaruhi kualitas hidupnya yang mencakup beberapa aspek salah satunya aspek psikologi (Abdullah et al., 2019).

American College of Obstetricians and Gynaecologists (ACOG) telah merekomendasikan untuk melakukan skrining psikologis setidaknya sekali selama kehamilan sebagai upaya deteksi dini gangguan kejiwaan (ACOG, 2018). Beberapa Intrumen untuk menilai tingkat kecemasan diantaranya Beck Depression Inventory (BDI) (13), Center for Epidemiologic Studies Depression Scale, Zung Self-Assessment Depression Scale, serta Hars. Pada penelitian ini peneliti menggunakan instrument HARS karena instrument ini lebih simple dan mudah digunakan serta hasilnya sangat akurat.

Dampak kecemasan pada Ibu hamil dan janin secara langsung dapat berkontibusi pada kematian ibu janin sehingga dapat meningkatkan Angka Kematian Ibu dan Angka Kematian Bayi. Penangganan yang tepat sangat dibutuhkan untuk mencegah dampak yang buruk. Masih kurangnya pengetahuan ibu hamil tentang teknik autogenic terutama ibu di lokasi Penelitian di Kabupaten Raja

ISSN 2655-2434 
Ampat mendorong Peneliti untuk melakukan penelitian ini sekaligus sebagai rekomendasi baru bagi Ibu hamil dan juga Bidan dalam Penelitian dengan judul "Pengaruh Penerapan Teknik Relaksasi Autogenik Terhadap Tingkat Kecemasan Ibu Hamil Primigravida".

\section{Metode}

Metode yang digunakan dalam penelitian ini adalah metode Quasi eksperimen, dengan desain one group pretest posttest. Variabel independen teknik relaksasia utogenik dan variabel dependen tingkat kecemasan ibu hamil. Hipotesis ada pengaruh teknik relaksasi autogenik terhadap tingkat kecemasan ibu hamil. Teknik relaksasi autogenik diberikan $3 x$ dalam seminggu dengan durasi 15-20 menit. Sedangkan tingkat kecemasan merupakan perasaan gelisah khawatir, dan tidak tentram yang disertai dengan gejala fisik seolah-olah akan terjadi hal buruk terhadap dirinya dan janin.

Pengukuran tingkat kecemasan menggunakan HARS (Hamilton Anxiety Rating Scale) dengan kategori tidak cemas jika Skor <14, Cemas ringan jika Skor 14-20, cemas sedang jika Skor 21-27, dan cemas berat jika skor 28-41 serta kecemasan sangat berat atau panic jika skor 42-56 (Aswitami, 2017). Populasi seluruh ibu hamil di wilayah kerja Puskesmas Waisai Kabupaten Raja Ampat tahun 2020 data Bulan Januari sampai dengan Maret berjumlah $312 \mathrm{Ibu}$ hamil dan $72 \mathrm{Ibu}$ merupakan ibu hamil primigravida trimester III. Sampel dalam penilitian ini adalah sebagian Ibu Primigravida Trimester III.

Sampel sebanyak 33 Responden, dihitung menggunakan rumus Analitik Kategori Berpasangan dengan teknik Purposive Sampling. Kriteria Inklusi Ibu Hamil Trimester III usia kehamilan 28 sampai dengan 40 minggu dan tidak ada komplikasi kehamilan serta bersedia menjadi responden. Waktu penelitian selama 1 bulan pada bulan Maret Tahun 2020. Data diolah menggunakan stastistik non parametrik dengan Uji Wilcoxon, untuk mengukur perbedaan 2 kelompok data berpasangan berskala ordinal.
Hasil penelitian yang dilakukan bulan Maret Sampai April 2020 pada 33 ibu hamil trimester III yang mengalami kecemasan di Wilayah Kerja Puskesmas Waisai Kabupaten Raja Ampat, diperoleh data sebagai berikut :

\section{Analisis Univariat}

\section{a. Karakteristik Responden}

Karakteristik Responden dalam Penelitian ini meliputi usia, pekerjaan dan tingkat pendidikan. Untuk lebih jelasnya dapat di lihat pada Tabel dibawah ini:

\begin{tabular}{|c|c|c|}
\hline Usia & Frekuensi & Presentase \\
\hline $18-35$ & 28 & 84,8 \\
\hline$<18->35$ & 5 & 15,2 \\
\hline Pekerjaan & Frekuensi & $\%$ \\
\hline Tidak Bekerja & 22 & 66.7 \\
\hline PNS & 5 & 15 \\
\hline Petani & 2 & 6 \\
\hline Lainnya & 4 & 12 \\
\hline Pendidikan & Frekuensi & $\%$ \\
\hline $\begin{array}{l}\text { Pendidikan } \\
\text { Dasar }\end{array}$ & 10 & 30,3 \\
\hline $\begin{array}{l}\text { Pendidikan } \\
\text { Lanjutan }\end{array}$ & 23 & 69,7 \\
\hline Total & 33 & $100 \%$ \\
\hline
\end{tabular}

Berdasarkan Tabel 1 diatas, kategori responden berdasarkan usia terbanyak pada usia 1835 tahun sebanyak berjumlah 28 responden $(84,8 \%)$, sedangkan yang paling sedikit yaitu berada pada usia 18 Tahun dan > 35 Tahun sebanyak 5 responden $(15,2 \%)$. Kategori responden berdasarkan jenis pekerjaan, terbanyak tidak bekerja berjumlah 22 responden $(66,7 \%)$ dan paling sedikit yaitu petani berjumlah 2 responden $(6,0 \%)$. Kategori responden berdasarkan tingkat pendidikan, terbanyak Pendidikan Lanjutan (SMA-Perguruan Tinggi) yaitu 23 responden $(69,7 \%)$ dan paling sedikit adalah Pendidikan Dasar (SD-SMP) yaitu 10 responden $(30,3 \%)$.

\section{Hasil}

(C) Poltekkes Kemenkes Jakarta I

Jl. Wijaya Kusuma No. 47-48 Cilandak Jakarta Selatan, Indonesia email: jurnalquality@poltekkesjakarta1.ac.id
Tabel 2

ISSN 2655-2434

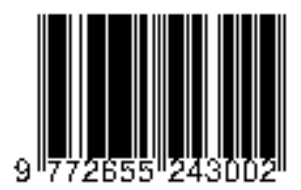


Rerata dan Standar Deviasi SebelumSesudah Intervensi

\begin{tabular}{llll}
\hline \multicolumn{2}{l}{ Sebelum } & Intervensi & \multicolumn{2}{c}{ Setelah Intervensi } \\
\hline $\begin{array}{l}\text { Rata- } \\
\text { rata }\end{array}$ & $\begin{array}{l}\text { Std. } \\
\text { Deviasi }\end{array}$ & Rata-rata & $\begin{array}{l}\text { Std. } \\
\text { Deviasi }\end{array}$ \\
\hline 0,710 & 0,843 & 0,235 & 0,485
\end{tabular}

Berdasarkan Tabel 2 diatas dapat dinyatakan bahwa rata-rata frekuensi kecemasan sebelum diberikan intervensi adalah 0,710 artinya rata-rata ibu tidak mengalami cemas dengan standar deviasi 0,843. Sedangkan rata-rata frekuensi setelah diberikannya intervensi adalah 0,235 artinya ada pengurangan ibu yang mengalami kecemasan setelah di berikan intervensi dengan standar deviasi 0,485 . Kesimpulan adanya penurunan tingkat kecemasan sesudah di berikan intervensi berupa teknik autogenic.

\section{Analisis Bivariat}

Tabel 3

Negative Ranks Dan Positive Ranks

Sebelum Dan Sesudah Intervensi

\begin{tabular}{|c|c|c|c|c|}
\hline \multicolumn{5}{|c|}{ Ranks } \\
\hline & & $\begin{array}{l}\text { Juml } \\
\text { ah }\end{array}$ & $\begin{array}{l}\text { Pering } \\
\text { kat } \\
\text { Rata- } \\
\text { rata }\end{array}$ & $\begin{array}{l}\text { Jumlah } \\
\text { dari } \\
\text { Peringk } \\
\text { atnya }\end{array}$ \\
\hline \multirow{2}{*}{$\begin{array}{l}\text { Sebelu } \\
\text { m- } \\
\text { Setelah } \\
\text { interve } \\
\text { nsi }\end{array}$} & $\begin{array}{l}\text { Negati } \\
\text { ve } \\
\text { Ranks }\end{array}$ & $20 \mathrm{a}$ & 10,50 & 210,00 \\
\hline & $\begin{array}{l}\text { Positiv } \\
\text { e } \\
\text { Ranks }\end{array}$ & $0 \mathrm{~b}$ & ,00 & ,00 \\
\hline
\end{tabular}

Berdasarkan Tabel 3 diatas dapat di nyatakan bahwa :

1) Negative Ranks atau selisih (negatif) antara frekuensi perubahan tingkat kecemasan untuk pretest dan posttest. Disini terdapat 20 data negatif $(\mathrm{N})$ yang artinya ke $33 \mathrm{ibu}$ mengalami perubahan tingkat kecemasan menjadi tidak cemas dari nilai pretest kenilai posttest

(C) Poltekkes Kemenkes Jakarta I

Jl. Wijaya Kusuma No. 47-48 Cilandak Jakarta Selatan, Indonesia email: jurnalquality@poltekkesjakarta1.ac.id
2) Positive Ranks atau selisih (positif) antara frekuensi kecemasan pada ibu untuk pretest dan posttest adalah 0 baik itu nilai N, Mean Rank, maupun Sum Rank. Nilai 0 ini menunjukan tidak adanya peningkatan frekuensi kecemasan dari nilai kecemasan pretest kenilai kecemasan posttest.

Tabel 4

\section{Hasil Analisis Sebelum Dan Sesudah Intervensi}

\begin{tabular}{|l|l|}
\hline \multicolumn{2}{|c|}{ Sebelum-Setelah Intervensi } \\
\hline $\mathrm{Z}$ & $-4,030 \mathrm{~b}$ \\
\hline Asymp. Sig. (2-tailed) &, 000 \\
\hline
\end{tabular}

Berdasarkan tabel 4 diatas diketahui nilai adalah 0,000 lebih kecil dari 0,05 maka kesimpulannya "Terdapat Pengaruh Teknik Relaksasi Aoutogenik Terhadap Penurunan Tingkat Kecemasan Pada Ibu Hamil Primigravida.

\section{Pembahasan}

Hasil penelitian menunjukkan terdapat pengaruh teknik relaksasi aoutogenik terhadap penurunan tingkat kecemasan pada ibu hamil primigravida trimester III. Penelitian ini sejalan dengan penelitian yang dilakukan pada 40 wanita primipara menunjukkan bahwa dengan intervensi autogenic secara signifikan dapat menurunkan tekanan darah sistolik, tekanan darah diastolik serta proteinuria pada ibu hamil dengan preeklamsia (Awad et al., 2019).

Hasil penelitan lain yang dilakukan pada pasien di ruangan Intensive Care Unit Rumah Sakit Pusri Palembang, menyatakan bahwa ada pengaruh teknik Relaksasi Autogenik terhadap kecemasan pasien di ruangan Intensive Care Unit Rumah Sakit Pusri Palembang (Rosida et al., 2019). Beberapa faktor yang dapat mempengaruhi tingkat kecemasan diantaranya faktor usia, pekerjaan, pendidikan. Pada faktor usia, sebagian besar responden berada pada rentang usia dewasa 26-35 tahun. Pada usia ini jelaskan ibu hamil secara fisik dan mental telah siap menghadapi kehamilan dan menghadapi proses persalinan walaupun ini merupakan pengalaman pertamanya. 
Hasil analisis didapatkan rata-rata pekerjaan responden adalah tidak bekerja, yang artinya ibu mempunyai banyak waktu untuk melakukan relaksasi aoutogenik secara optimal karena pada kelompok ini mereka memiliki waktu luang di rumah yang lebih banyak dari ibu bekerja. Pada tingkat pendidikan responden terbanyak adalah tamat sekolah menengah atas, semakin tinggi pendidikan seseorang maka pola berpikirnya dan daya tanggap terhadap informasi yang berikan akan lebih mudah. Penyerapan informasi lebih mudah dipahami berbagai informasi baik melalui sosialisasi, konseling maupun media, sehingga lebih memiliki pemahaman mengenai relaksasi autogenik.

Penelitian terkait teknik relaksasi aoutogenik terhadap penurunan tingkat kecemasan, telah banyak dilakukan namun penelitian yang memfokuskan pada ibu hamil primigravida pada trimester III Masih sangat jarang. Selain itu, ini merupakan penelitian pertama dengan lokasi Puskesmas Waisai. Hal ini sekaligus merupakan kebaharuan dari penelitian ini, sehingga hasil penelitian ini dapat menjadi solusi dan rekomendasi baru dalam penanganan kasus kecemasan Ibu menghadapi persalinan.

\section{Kesimpulan dan Saran}

Teknik relaksasi autogenik terbukti berpengaruh terhadap menurunkan tingkat kecemasan pada ibu hamil primigravida. Saran kepada praktisi Bidan dapat menerapkan teknik autogenic sebagai salah satu penangganan alternative dalam menanggani kecemasan pada ibu hamil Primigravida.

\section{Daftar Pustaka}

Abdullah, V. I., Permadi, W., \& Susiarno, H. (2019). Differences of Quality Of Life Between Men And Women Of Reproductive Age Suffering Human Immunodeficiency Virus Infection By Using The Instrument Whoqol - Hiv Bref In Clinic Mawar Bandung City. 3(1), 1-7.

ACOG. (2018). Screening For Perinatal Depression. Replaces Committee Opinion, 132(757), 208-212.

Article, R. (2020). Review Article Decreased

(C) Poltekkes Kemenkes Jakarta I

Jl. Wijaya Kusuma No. 47-48 Cilandak Jakarta Selatan, Indonesia email: jurnalquality@poltekkesjakarta1.ac.id
Anxiety Levels, And Cortisol Levels Through Primigravida. 7(5), 193-196.

Aswitami, N. G. A. P. (2017). Pengaruh Yoga Antenatal Terhadap Tingkat Kecemasan Pada Ibu Hamil Tw Iii Dalam Menghadapi Proses Persalinan Di Klinik Yayasan Bumi Sehat. Jurnal Kesehatan Terpadu, 1(1), 15. Https://Doi.Org/10.36002/Jkt.V1i1.155

Awad, M. A., Hasanin, M. E., Taha, M. M., \& Gabr, A. A. (2019). Effect Of Stretching Exercises Versus Autogenic Training On Preeclampsia. Journal of Exercise Rehabilitation, 15(1), 109-113. Https://Doi.Org/10.12965/Jer.1836524.26 2

Di, H., \& Lismarini, B. P. M. (2018). Poltekkes Kemenkes Palembang Bpm Kustirah Palembang Tahun 2018: Sulastri Program Studi D-Iv Kebidanan.

Manalu, A. B., Siagian, N. A., Yanti, M. D., Yessy, P. A., Barus, D. T., \& Purba, T. J. (2020). Pengaruh Pemberian Relaksasi Autogenik Terhadap Tingkat Kecemasan Ibu Primigravida Di Bpm Kurnia Kecamatan Deli Tua Kabupaten Deli Serdang. 5(1), 6-13.

Mumtaz, S., \& Akram, B. (2020). Management Of Anxiety Among Pregnant Women With Serious Medical Conditions: A Multicentre Study. JPMA. The Journal Of The Pakistan Medical Association, 70(11), 1966-1969. Https://Doi.Org/10.5455/JPMA.47636

Omidvar, S., Faramarzi, M., Hajian-Tilak, K., \& Amiri, F. N. (2018). Associations Of Psychosocial Factors With Pregnancy Healthy Life Styles. Plos ONE, 13(1), 113.

Https://Doi.Org/10.1371/Journal.Pone.019 1723

Pinto, T. M., Caldas, F., Nogueira-Silva, C., \& Figueiredo, B. (2017). Depressão E Ansiedade Maternal E Crescimento FetalNeonatal. Jornal De Pediatria, 93(5), 452459.

Https://Doi.Org/10.1016/J.Jped.2016.11.0 
05

Rosida, L., Imardiani, I., \& Wahyudi, J. T. (2019). Pengaruh Terapi Relaksasi Autogenik Terhadap Kecemasan Pasien Di Ruang Intensive Care Unit Rumah Sakit Pusri Palembang. Indonesian Journal For Health Sciences, 3(2), 52. Https://Doi.Org/10.24269/Ijhs.V3i2.1842

Salgado, I. V., Mendoza, J. L. M., \& Zerón, H. M. (2020). Mexican Pregnant Women Show Higher Depression And Anxiety With Rising Age And In The Case Of Being Single. Acta Medica Lituanica, 26(4), 227-236. Https://Doi.Org/10.6001/Actamedica.V26 i4. 4208

Umam, E. R., Sulistyono, A., \& Yunitasari, E. (2020). The Effect Of A Combination Of Autogenic And Benson Relaxation On Sleep Quality Among Pregnant Women With Hypertension. 3(4), 501-506. 